\title{
„Dziki Zachód” Państwa Środka - bezpieczeństwo i gospodarka w chińskiej polityce wobec prowincji Xinjiang
}

\begin{abstract}
$\mathrm{O}$ D PONAd DWudziestu lat Chińska Republika Ludowa (ChRL) prowadzi aktywną działalność na rzecz odbudowania politycznych, gospodarczych i kulturalnych więzi z Azją Środkową ${ }^{1}$. Kluczową rolę w tym procesie odgrywa Xinjiang - jedyna chińska prowincja bezpośrednio granicząca z państwami środkowoazjatyckimi. Jednocześnie jest to obszar, na którym stykają się kwestie natury bezpieczeństwa energetycznego, zagrożeń o charakterze asymetrycznym i rozwoju społeczno-gospodarczego w warunkach systemu autorytarnego. Celem niniejszego artykułu jest przedstawienie chińskiej polityki wobec swej zachodniej prowincji, zarówno w kontekście modelu rozwoju realizowanego przez rząd w Pekinie, jak również wyzwań związanych z zapewnieniem bezpieczeństwa na tym obszarze.

Zgodnie z przyjętym w 1955 r. statutem Xinjiang określany jest jako Ujgurski Region Autonomiczny (URA). Dzieli on z Kazachstanem, Kirgistanem i Tadżykistanem wspólną granicę wynoszącą ponad 3000 km. Graniczy także z Pakistanem, Afganistanem i Indiami. Jest to największa spośród chińskich prowincji o powierzchni równej $1,66 \mathrm{mln} \mathrm{km}^{2}$ (1/6 terytorium kraju), zaludniona przez 21,81 $\mathrm{mln}$ ludności, co stanowi jedynie $1,52 \%$ populacji ChRL ${ }^{2}$. To przez jej terytorium przebiegał słynny Szlak Jedwabny, będący do czasu wiel-
\end{abstract}

\footnotetext{
${ }^{1}$ Pod pojęciem Azji Środkowej autor ma na myśli pięć republik środkowoazjatyckich, które po rozpadzie ZSRR w 1991 r. znalazły się w gronie 15 nowopowstałych państw. Są to: Kazachstan, Uzbekistan, Turkmenistan, Kirgistan oraz Tadżykistan. Wyjaśnienie użytej terminologii wydaje się zasadne w celu uniknięcia nieporozumień w związku $\mathrm{z}$ istnieniem w szeregu prac naukowych różnego spektrum geograficznego dla terminu Azja Środkowa. Uwzględnia ona historyczne, kulturowe, polityczne, a przede wszystkim gospodarcze powiązania 5 państw będących przez ponad 150 lat częścią Imperium Rosyjskiego a następnie ZSRR.

${ }^{2}$ Komunikat Narodowego Biura Statystycznego ChRL dotyczacy Narodowego Spisu Powszechnego, http://www.stats.gov.cn/english/newsandcomingevents/ t20110429_402722516.htm, 27.02.2012 r.
} 
kich odkryć geograficznych główną drogą handlową, łączącą Europę z Chinami i Bliskim Wschodem. Powiązania gospodarcze i polityczne regionu z Państwem Środka sięgają więc tysiącleci. Jednak dopiero na początku XVIII w. Chinom udało się go na dobre podporządkować3. Nadana mu nazwa Xinjiang, oznacza w języku chińskim „nowe terytorium” lub „nową granicę”"

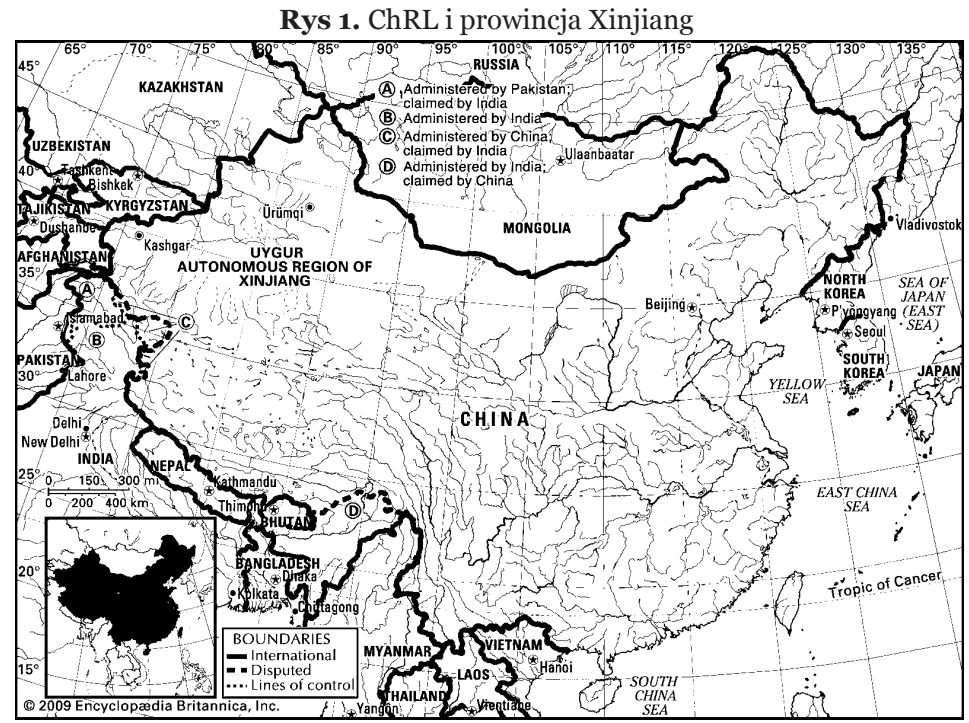

Źródło: Xinjiang, [w:] Encyklopedia Britannica, http://www.britannica.com/EBchecked/topic/546118/Xinjiang, 28.02.2012.

Region ten od początku chińskiego panowania charakteryzował się wewnętrzną niestabilnością. W latach 1825 i 1865 miały miejsce antychińskie powstania pod wodzą ujgurskiego warlorda - Yakuba Bega. Kolejna rebelia wybuchła w 1931 r. obalając niepopularnego gubernatora prowincji Jin Shurena. W jej wyniku w 1933 r. proklamowano powstanie Republiki Turkiestanu Wschodniego. Początek lat 30. $\mathrm{XX}$ w. to okres w którym prowincja stała się celem marszu wielu armii, od chińskich muzułmanów dowodzonych przez Ma Zhongyinga, armie gubernatora chińskiego mianowanego przez Nankin czy zwolenników

${ }^{3}$ G. R. Capisani, Nowe państwa Azji Środkowej, Warszawa, 2004, s.319.

${ }^{4}$ Xinjiang, [w:] Encyklopedia Britannica, http://www.britannica.com/EBchecked/ topic/546118/Xinjiang, 28.02.2012 r. 
niepodległości. W 1934 r. Chinom udało się odzyskać kontrolę nad regionem. Nie trwało to jednak długo, bowiem już w 1940 r. po raz kolejny proklamowano powstanie Republiki Wschodniego Turkiestanu. Na czele nowego powstania stanął Saifuddin Azizi - Ujgur wykształcony w Taszkiencie, a zarazem członek Partii Komunistycznej Związku Radzieckiego. Status prowincji uregulowano ostatecznie poprzez podpisanie traktatu między ZSRR a Chinami, w którym to Xinjiang uznany został za część terytorium chińskiego.

Dotychczasowi przywódcy powstania wstąpili do Chińskiej Partii Komunistycznej. Sam Saifuddin został szefem prowincjonalnego rządu do 1978 r. odgrywając znaczącą rolę w regionie ${ }^{5}$.

\section{Problemy etnicZne}

INTENSYWNA PROCES ROZPRZESTRZENIANIA SIĘ CHIŃSKIEJ KULTURY i jęZyka w Xinjiang systematycznie zmienia jego strukturę narodowościową. Niemalże połowę (45\%) mieszkańców obszaru stanowią, wyznający Islam i wywodzący się z grupy ludów tureckich, Ujgurzy. Zwiększa się natomiast odsetek Chińczyków Han (ok. 40\%), którzy już teraz stanowią większość w dużych aglomeracjach miejskich. Prowincje zamieszkują także Kazachowie (ok. 7\% populacji), wyznający islam Chińczycy Hui, Tadżycy, Kirgizi oraz ludność mongolska ${ }^{6}$.

Zróżnicowaniu narodowościowemu towarzyszy silne rozwarstwienie majątkowe pomiędzy lepiej sytuowaną ludnością Han, a mniejszościami (tabela 1). Wpływa to na rosnący niepokój wśród Ujgurów, zarzucających Pekinowi traktowanie ich jako obywateli drugiej kategorii, obawiających się stopniowej asymilacji językowej i kulturowej. W styczniu 1997 r. w mieście Yining, w północnozachodniej części prowincji, tradycyjny ujgurski wiec mężczyzn - meshrep - przekształcił się w dwudniową demonstrację przeciwko egzekucji dwudziestu działaczy niepodległościowych i chińskiej obecności w Xinjiangu.

Demonstracja została stłumiona przez wojsko, w wyniku czego śmierć poniosło, według oficjalnych danych dziewięć osób7. Nieoficjalne źródła podają znacznie wyższe liczby, sięgające nawet kilkuset zabitych protestantów ${ }^{8}$. W lutym tego samego roku, w dniu oficjalnego

\section{${ }^{5}$ Ibidem.}

${ }^{6}$ Ibidem.

${ }^{7}$ BBC World Sercvice, China Uighurs executed, , http://news.bbc.co.uk/2/hi/asia-pacific/50936.stm, 27.02.2012 r.

${ }^{8}$ Remember the Gulja massacre? China's crackdown on peaceful protesters , Amnesty International in Asia and the Pacific, http://asiapacific.amnesty.org/apro/ 
pogrzebu Deng Xiaopinga, miała miejsce seria zamachów bombowych w Urumqi, stolicy URA. Dziesięć dni później ujgurscy ekstremiści wysadzili w powietrze autobus w Pekinie. Był to pierwszy znany przypadek zamachu terrorystycznego w stolicy ChRL od czasu rewolucji 1949 r. ${ }^{9}$. Niezależnie od rozbieżności w napływających informacjach, to przede wszystkim wydarzenia $z$ lat 90. doprowadziły do radykalizacji, zarówno chińskiej polityki wobec prowincji, jak i działalności ujgurskich separatystów. Duże znaczenia miał także upadek w 1991 r. Związku Socjalistycznych Republik Radzieckich (ZSRR) i uzyskanie niepodległości przez pięć środkowoazjatyckich republik, posiadających bliskie więzi kulturowe i językowe z zamieszkującymi Xinjiang Ujgurami $^{10}$. Nowi sąsiedzi stanowili doskonały przykład na to, iż uwolnienie się spod zależności komunistycznego hegemona jest możliwe, co z kolei zachęcało zwolenników separatyzmu do aktywnej walki o uzyskanie niepodległość.

Tabela 1. Etniczna redystrybucja $\mathrm{PKB}$ per capita w prowincji Xinjiang na podstawie cen z $2002 \mathrm{r}$.

\begin{tabular}{|l|c|c|c|}
\hline \multicolumn{1}{|c|}{ Miasta } & \multicolumn{2}{|c|}{ \% Populacji } & $\begin{array}{c}\text { PKB per capita } \\
\text { (yuan) }\end{array}$ \\
\hline & Ujgurzy & Han & 1,977 \\
\hline Khotan & 96,8 & 3 & 2,650 \\
\hline Kaszgar & 89 & 9,4 & 5,429 \\
\hline Aksu & 72,8 & 25,9 & 13,059 \\
\hline Turpan & 69 & 24,2 & 2,468 \\
\hline Kizilsu & 63,7 & 5,9 & 7,815 \\
\hline Hami & 18,4 & 68,8 & 45,033 \\
\hline Karamay & 13,8 & 77,6 & 17,780 \\
\hline Urumqi & 12,7 & 73,5 & 10,973 \\
\hline Shihezi & 1,2 & 94,7 & \\
\hline
\end{tabular}

Źródło: Henryk Szadziewski, How the West was Won: China's expansion into Cenral Asia, Caucasian Review of International Affairs 2009, nr 3.

aproweb.nsf/pages/appeal_china_gulja, 27.02.2012 r.

9 J. Ben-Adam Rudelson, UYGHUR "SEPARATISM": CHINA'S POLICIES IN XINJIANG FUEL DISSENT, CACI Analyst, 2000.

${ }^{10}$ Wyjątkiem jest Tadżykistan, w którym do dziś pozostały silne wpływy perskie, zarówno w języku jak i w kulturze. 


\section{BEZPIECZEŃSTWO}

PrZeZ LATA TO NIEWĄTPLIWIE KWESTIE BEZPIECZEŃstwa stały się dominującym elementem w polityce prowadzonej przez ChRL wobec URA. W 1998 r. rozpoczęto rządową kampanię o nazwie „Mocne Uderzenie”, której głównym celem stała się walka z wszelkimi objawami separatyzmu, terroryzmu i bandytyzmu $\mathrm{w}$ prowincji ${ }^{11}$. Oprócz masowych aresztowań i obostrzeń nałożonych na religijne i świeckie organizacje działające w Xinjiangu, dążono także do ograniczenia kontaktów z ujgurską diasporą w Azji Środkowej. Chińskie naciski na Kazachstan i Kirgistan doprowadziły do zamknięcia gazet wydawanych w języku ujgurskim w tych państwach, a także Instytutu Ujgurskiego działającego w Ałma Acie w ramach Wydziału Orientalistycznego ${ }^{12}$. Ujgurów odsunięto od roli pośredników w handlu pomiędzy ChRL a postradziecką Azją Środkową, mimo iż odgrywali oni dominującą rolę w stymulacji odradzających się relacji handlowych w regionie.

Jaskrawym tego przykładem jest postać Rebiji Kadir, ujgurskiej biznesmenki, która po rozpadzie ZSRR zaangażowała się w handel przygraniczny z państwami postradzieckimi, szybko uzyskując status jednej z najbogatszych kobiet w Chinach. Kadir brała udział w obradach Ludowej Politycznej Konferencji Konsultatywnej Chin (LPKKC) - instytucji doradczej dla organów rządowych, a także w Światowej Konferencji w sprawie Kobiet, gdzie reprezentowała ChRL ${ }^{13}$. Po wydarzeniach z stycznia 1997 r. rozpoczęła ostrą krytykę chińskiej polityki wobec Xinjiangu i aktywną działalność na rzecz umiędzynarodowienia problemu ujgurskiego. W 1999 r. została aresztowana i oskarżona o stwarzanie zagrożenia dla bezpieczeństwa państwa. W więzieniu spędziła ponad 5 lat $^{14}$. Obecnie mieszka w USA pełniąc jednocześnie funkcje prezydenta Światowego Kongresu Ujgurów - jednej z największych międzynarodowych organizacji zrzeszających ujgurską diasporę ${ }^{15}$.

${ }^{11}$ Remember the Gulja massacre? China's crackdown on peaceful protesters, $\mathrm{Hu}-$ man Rights Watch Backgrounder, http://www.hrw.org/legacy/backgrounder/asia/china-bck1017.htm, 27.02.2012 r.

${ }^{12}$ S. Peyrouse, Economic Aspects of the Chinese-Central Asia Rapprochement, Silk Road Paper 2007, s. 12.

13 Profile: Rebiya Kadeer, BBC News, http://news.bbc.co.uk/2/hi/asia-pacific/4357607.stm, 27.02.2012 r.

${ }_{14}$ A. Cacvelius, R. Kadir, Szturmujac Niebo Opowieść o życiu chińskiego wroga numer jeden, Wołowiec 2011, s. 342.

15 Introducing the World Uyghur Congress, The World Uyghur Congress, http://www.uyghurcongress.org/en/?cat=149, 28.02.2012 r. 
Równoległe z realizacją przez władzę opresyjnej polityki wobec prowincji, postępującej radykalizacji ulegał ruch separatystyczny, którego różne odnogi coraz częściej nawoływały do aktów zbrojnego oporu. W 2008 r. doszło do serii incydentów terrorystycznych, w tym próby wysadzenia samolotu pasażerskiego chińskich linii China Southern Airlines ${ }^{16}$ oraz ataku na komendę policji w Kaszgarze, w którym zginęło siedemnastu policjantów, a piętnastu zostało rannych. Ten ostatni miał miejsce zaledwie cztery dni przed rozpoczęciem igrzysk w Pekinie $^{17}$. 5 lipca 2009 r. w zamieszkach w Urumqi śmierć, według chińskich danych, poniosły sto osiemdziesiąt cztery osoby, a ponad sto zostało rannych. W kolejnym roku samobójczy zamach w miejscowości Aksu pozbawił życia piętnastu policjantów ${ }^{18}$.

Odpowiedzialnością za akty terrorystyczne w prowincji Chińczycy obarczają grupy separatystyczne takie, jak Ujgurska Organizacja Wyzwolenia, Organizacja Wyzwolenia Wschodniego Turkiestanu, Islamski Ruch Wschodniego Turkiestanu czy Zjednoczony Rewolucyjny Front Wschodniego Turkiestanu. Ich potencjał do prowadzenia aktywnej działalności terrorystycznej wydaje się jednak być celowo wyolbrzymiany przez Państwo Środka, w celu uzasadniania restrykcyjnej polityki wobec prowincji. Często także wydarzenia, które przedstawiane są przez władzę jako przejaw separatyzmu ujgurskiego, mają charakter czystko kryminalny, a próby powiązania ich z wyżej wymienionymi grupami mają w dużej mierze wydźwięk propagandowy.

Wyjątkiem jest działalność Islamskiego Ruchu Wschodniego Turkiestanu (ETIM) - organizacji terrorystycznej dążącej do stworzenia niepodległego „Wschodniego Turkiestanu”, otwarcie przyznającej się do przeprowadzenia ponad dwustu aktów terroryzmu w ChRL ${ }^{19}$. ETIM, w odróżnieniu od pomniejszych grup działających w prowincji, posiada pewien potencjał militarny, logistyczny oraz siatkę powiązań z grupami takimi, jak Al-Kaida czy Islamski Ruch Uzbekistanu (IRU). W styczniu 1996 r. po udanej operacji rozbicia jednego z przyczółków ETIM, na miejscu znaleziono $3000 \mathrm{~kg}$ materiałów wybuchowych, 4000 lasek dynamitu, oraz sześciuset sztuk broni wraz z amunicją ${ }^{20}$.

${ }^{16}$ E. Van Wie Davis, China confronts its Uyghur threat Asia Times Online, http://www.atimes.com/atimes/China/JD18Ado1.html, 27.02.2012 r.

${ }_{17}$ Chiny - Xinjiang, http://www.stosunkimiedzynarodowe.info/kraj,Chiny,prooblemy,Xinjiang, 27.02.2012 r.

${ }^{18} \mathrm{~S}$. Rabinovitch, China detains four over attack on Xinjiang police, Agencja Reutera, http://www.reuters.com/article/2010/o8/25/idUSTOE67Oo8I, 27.02.2012 r.

${ }_{19}$ http://www.msnbc.msn.com/id/4686228/, 27.02.2012 r.

${ }^{20}$ R. Gunaratna, K. G. Pereire, An Al.-Qaeda associate Group Operating in China?, 
Powiązania z międzynarodowymi siatkami terrorystycznymi umożliwiają ETIM tworzenie obozów szkoleniowych na terenach Afganistanu, Pakistanu i Azji Środkowej, z których następnie jej członkowie zostają przerzucani do Chin. To właśnie w jednej z takich kryjówek na granicy pakistańsko-afgańskiej ukrywał się przywódca ETIM Hasan Mahsum, zastrzelony w 2003 r. w czasie starcia sił Al-Kaidy z pakistańską armią ${ }^{21}$.

We wrześniu 2002 r. ETIM znalazł się na amerykańskiej liście organizacji terrorystycznych ${ }^{22}$. Ruch ten ze strony USA wynikał głównie z chęci pozyskania chińskiego wsparcie w swojej kampanii przeciw globalnemu terroryzmowi, natomiast dla rządu w Pekinie oznaczał międzynarodową legitymację do działań prowadzonych w regionie. W tym samym roku, gdy wojska amerykańskie prowadziły ofensywę w Afganistanie, około 40 tys. chińskich żołnierzy przeniesiono w głąb $\mathrm{URA}^{23}$. Ich głównym celem było utrzymanie bezpieczeństwa w prowincji i prowadzenie dalszych działań skierowanych przeciwko działalności kryminalnej i terrorystycznej. Skala przedsięwzięcia doskonale obrazuje powagę, z jaką rząd centralny traktuje problem separatyzmu $\mathrm{w}$ prowincji, a która wynika z obawy przed rozprzestrzenieniem się antychińskich nastrojów na pozostałe części wieloetnicznego państwa.

Chiny, oprócz działalności o charakterze militarnym, są jednym z głównych inicjatorów regionalnej współpracy antyterrorystycznej na forum Szanghajskiej Organizacji Współpracy (SOW). Ta międzyrządowa organizacja powstała w 2001 r., oprócz ChRL zrzesza Rosje oraz cztery państwa środkowoazjatyckie (Kazachstan, Uzbekistan, Tadżykistan i Kirgistan). Wykształciła się z pięcioletniej współpracy pomiędzy jej członkami dotyczącej uregulowania kwestii granic z Chińską Republiką Ludową po rozpadzie ZSRR. Z czasem jednym z głównych celów SOW stała się budowa wzajemnego obszaru bezpieczeństwa oraz walka z tzw. „trzema złami”: terroryzmem, ekstremizmem i separatyzmem ${ }^{24}$.

Działalność SOW ułatwić ma koordynacje współpracy w walce z opisanymi zjawiskami i stworzyć pewne odgórne mechanizmy po-

\footnotetext{
„China and Euroasia Forum Quarterly” 2006, nr 2, s. 59.

${ }^{21}$ http://news.bbc.co.uk/2/hi/asia-pacific/3343241.stm, 27.02.2012 r.

${ }^{22}$ Stosunki dwustronne Chiny-USA, http://www.stosunkimiedzynarodowe.info/ kraj,Chiny,stosunki_dwustronne,USA, 27.02.2012 r.

${ }^{23}$ M. Moneyhon, Taming China's “Wild West”: Ethnic Conflict in Xinjiang, „Peace, Conflict and Development Journal” 2003, s.3.

${ }^{24}$ SCO: 10 years of cooperation, Agencja Xinhua, http://news.xinhuanet.com/english2010/video/2011-11/o7/c_131233234.htm, 28.02.2012 r.
} 
stępowania. W 2004 r. w ramach tej organizacji powstała Regionalna Struktura Antyterrorystyczna (RSA), która jest odpowiedzialna za badanie aktywności regionalnych ruchów terrorystycznych. Stanowi ona jednocześnie centrum wymiany informacji między służbami bezpieczeństwa każdego z państw. Według Dyrektora Komitetu Wykonawczego RSA W. Kasymowa dzięki istnieniu tego organu do roku 2005 zdołano zapobiec ponad 250 aktom terrorystycznym ${ }^{25}$. Organizowane są również ćwiczenia wojskowe symulujące starcia z siłami terrorystycznymi. Pierwsze tego typu ćwiczenia, w których udział wzięło około 1000 żołnierzy z wszystkich państw członkowskich odbyły się w 2003 r. w Kazachstanie. W kolejnych latach skala działania oraz wydatki na organizacje manewrów znacznie wzrosły. W 2005 r. w chińsko-rosyjskich ćwiczeniach pod egidą SOW udział wzięło już ponad 10 ooo żołnierzy ${ }^{26}$.

Aktywność ChRL na forum SOW wynika ze zrozumienia silnej korelacji pomiędzy bezpieczeństwem Xinjiangu a sytuacją w Azji Środkowej. Według Państwa Środka ewentualna destabilizacja regionu środkowoazjatyckiego może doprowadzić do umocnienia się radykalnego Islamu, który następnie wraz z bronią i pieniędzmi zostanie „wyeksportowany” do Xinjiangu. Niepokój Chin budzi również blisko półmilionowa diaspora Ujgurska w Azji Środkowej (szczególnie silna w Kazachstanie) ${ }^{27}$. Niektórzy jej członkowie podejrzewani są o wspieranie finansowe działalności terrorystycznej lub utrzymywanie kontaktów i współpracy z IRU i innymi pantureckimi bądź panislamskimi organizacjami. Obszar Azji Środkowej stanowi również ważną trasę przerzutową narkotyków z Afganistanu do Europy i Chin. Statystycznie ponad połowa heroiny dostarczanej do Europy i Ameryki Północnej transportowana jest z Afganistanu przez terytoria Azji Środkowejé, a jeszcze w 2006 r. dane sugerowały iż nawet połowa gospodarczej aktywności mieszkańców Tadżykistanu może być związana z handlem narkotykami ${ }^{29}$. Proceder ten często stanowi lukratywne źródło finan-

${ }^{25} \mathrm{~F}$. Tolipov, Multilateralism, Bilateralism and Unilateralism in Fighting Terrorism in the SCO Area, „The China and Eurasia Forum Quarterly” 2006, nr 2, s. 168.

${ }^{26}$ R. N. McDermott, THE RISING DRAGON:SCO Peace Mission 2007, „The Jamestown Foundation Occasional Paper" 2007, s. 6

${ }^{27}$ E. Van Wie Davis, Uyghur Muslim Ethnic Separatism in Xinjiang, China, „AsiaPacific Center for Security Studies” 2008, s. 8

${ }^{28}$ S. Kardaś, Środkowoazjatycki wektor polityki zagraniczne federacji rosyjskiej za prezydentury Wtadimira Putina, [w:] Rosja w okresie prezydentury Władimira Putina, red. A. Stępień-Kuczyńska, S. Bieleń, Łódz-Warszawa-Toruń 2008, s. 328.

${ }^{29}$ W. Byrd, M. Raiser, A. Dobronogov, A. Kitain, Economic Cooperation in the Wi- 
sowania dla działalności terrorystów. Skuteczna współpraca pomiędzy państwami pomóc ma w odcięciu ruchów separatystycznych od zewnętrznych źródeł pomocy, a także ograniczeniu możliwości przepływu broni i narkotyków na terytorium chińskiej prowincji.

\section{GOSPODARKA}

WYDAWAEOBY SIĘ, IŻ NA TLE PROBLEMÓW związanych z bezpieczeństwem i terroryzmem, wymiar gospodarczy chińskiej polityki wobec Xinjiang może zostać zaniedbany. Tak się jednak nie stało. Chińczycy od kilkudziesięciu lat skutecznie realizują program stopniowej transformacji gospodarczej największej spośród swych prowincji, a kwestie natury ekonomicznej powoli stają się dominującymi w dyskusjach na temat obecnej sytuacji w URA.

Dla rozpędzonej gospodarki ChRL prowincja Xinjiang jest istotna z dwóch zasadniczych względów. Po pierwsze ze względu na bogactwo surowców naturalnych. Znajduje się tu 25\% chińskich rezerw ropy i gazu $^{30}$ i około $40 \%$ zasobów węgla ${ }^{31}$. Przy obecnym stanie konsumpcji zasoby węgla znajdujące się w Xinjiangu zaspokoiłyby światowy popyt na ten surowiec przez 364 lata $^{32}$. Po drugie URA jest węzłem komunikacyjnym, który łączączy Chiny z Azją Środkową i dalej z Europą oraz Bliskim Wschodem. Pełni więc istotną rolę w stymulacji handlu i rozwoju stosunków gospodarczych w regionie środkowoazjatyckim oraz zapewnieniu bezpieczeństwa energetycznego kraju, poprzez import ropy i gazu od swych zachodnich sąsiadów.

W 2000 r. Xinjiang jako jeden z pięciu autonomicznych regionów i sześciu prowincji został objęty strategią „otwarcia na zachód” (The Great Western Development Plan, Open Up the West Program). Głównym celem tej szeroko zakrojonej kampanii było zlikwidowanie nierówności w rozwoju gospodarczym pomiędzy bogatymi regionami południowo-wschodnimi, a „biednym zachodem”. Zachodnie regiony stanowiące $71 \%$ całkowitej powierzchni Chin $\left(6,85 \mathrm{mln} \mathrm{km}^{2}\right)$ i zamieszkałe przez ponad $28 \%$ populacji biorą udział w tworzeniu jedynie $17 \%$ chińskiego $\mathrm{PKB}^{33}$. W odniesieniu do Xinjiangu skupiono

der Central Asia Region, „World Bank Working Paper” 2006, No. 75, s. 14.

${ }^{30} \mathrm{H}$. Szadziewski, How the West was Won: China's expansion into Cenral Asia, „Caucasian Review of International Affairs” 2009, nr 3, s. 215.

${ }^{31}$ Xinjiang Province, World Coal Association, http://www.worldcoal.org/resources/ecoal/ecoal-current-issue/xinjiang-province/, 27.02.2012 r.

${ }^{32}$ Ibidem.

${ }^{33}$ H. Szadziewski, How the West was Won: China's expansion into Cenral Asia, 
się przede wszystkim na masowych inwestycjach w projekty związane z eksploatacją zasobów naturalnych, rozwojem przemysłu petrochemicznego i infrastruktury transportowej. Prowincja otrzymała na to wsparcie przekraczające osiem mld dolarów ${ }^{34}$. Program dał początek zintensyfikowanej polityce inwestycyjnej na tym obszarze, realizowanej w kolejnych planach pięcioletnich.

Plan na lata 2011-15 zakłada przekształcenie URA w krajowe centrum petrochemii i przemysłu energetycznego. Inwestycje samych przedsiębiorstw państwowych w prowincji przekroczą zapewne 158 mld dolarów ${ }^{35}$. To właśnie rafinerie w Xinjiangu dokonają niezbędnego procesu przerobu ropy naftowej i gazu importowanych z Azji Środkowej, a w przyszłości także z Bliskiego Wschodu, by jako benzyna i produkty ropopochodne mogły zostać przesłane do pozostałych części kraju. Działania te wpisują się w element długofalowej strategii zapewnienia bezpieczeństwa energetycznego ChRL, zajmującej obecnie drugie miejsce - zaraz po USA - pod względem konsumpcji energii na świecie ${ }^{36}$.

Chińczycy implementują w URA również rozwiązania z południowowschodnich prowincji, sprawdzone w czasie transformacji gospodarczej w latach 8o. Z terytorium prowincji wydzielane zostają tzw. Specjalne Strefy Ekonomiczny (SSE) - obszary o preferencyjnych warunkach dla funkcjonowania podmiotów gospodarczych. W każdym przypadku ściśle określany jest charakter branż, jakie skupiać ma w sobie dana SSE. Do 2020 r. w planach jest stworzenie dwóch SSE na terytorium Xinjiangu. Pierwsza z nich znajdzie się w graniczącym z Kazachstanem mieście Khorgos i skupi się na rozwoju odnawialnych źródeł energii, branży tekstylnej oraz elektroniki. Druga ulokowana zostanie w Kashgarze, mieście uważanym za największe targowisko środkowoazjatyckie. Będzie pełnić role logistycznego i handlowego centrum kontaktów gospodarczych z zachodnimi sąsiadami ChRL. Celem obu z nich stanie się przyciąganie krajowych i zagranicznych inwestycji, ale także stworzenie bazy dla chińskiej ekspansji gospodarczej na środkowoazjatyckie i bliskowschodnie rynki ${ }^{37}$.

„Caucasian Review of International Affairs” 2009, nr 3, s. 211.

34 S. Peyrouse, Economic Aspects of the Chinese-Central Asia Rapprochement,

SILK ROAD PAPER September 2007, s. 17.

${ }^{35}$ C. Jia, M. Weihua, Xinjiang's economy set to be transformed, China Daily, http:// www.chinadaily.com.cn/business/2011-09/15/content_13690476.htm, 27.02.2012 r.

${ }^{36}$ China - Country Analysis Brief, U.S. Energy Information Administration, http://205.254.135.7/countries/country-data.cfm?fips=CH, 27.02.2012 r.

372 economic zones to be built in Xinjiang by 2020, China Daily, http://usa.china- 
Z tego samego powodu Chińczycy wspierają inwestycje związane z infrastrukturą, łączącą Xinjiang z sąsiednimi państwami. Przykładem może być budowa $400 \mathrm{~km}$ autostrady Irkeshtam-Osh łączącej jedno z głównych chińsko-kirgiskich przejść granicznych z drugim co do wielkości miastem Kirgistanu ${ }^{38}$, czy też tzw. Kolei Północnego Xinjiangu, mającej skrócić dystans między Urumqi a Ałma Atą ${ }^{39}$. W latach 2006-2011 tylko na rozwój infrastruktury transportowej w URA przeznaczono ponad dziesięć mld dolarów ${ }^{40}$. Tworzone połączenia mają także stanowić element większej sieci komunikacyjnej, która w przyszłości połączy Chiny z Europą i Bliskim Wschodem ${ }^{41}$.

Tabela 2 Obroty handlowe pomiędzy Chinami a innymi członkami SOW (w tys. USD)

\begin{tabular}{|l|c|c|c|}
\hline \multicolumn{1}{|c|}{ Kraj } & $\mathbf{2 0 0 1}$ & $\mathbf{2 0 0 5}$ & Wzrost \\
\hline Kazachstan & $1,288,370$ & $6,810,320$ & $429 \%$ \\
\hline Kirgistan & 118,860 & 972,200 & $718 \%$ \\
\hline Tadżykistan & 10,760 & 157,940 & $1,368 \%$ \\
\hline Uzbekistan & 58,300 & 680,560 & $1,067 \%$ \\
\hline
\end{tabular}

Źródło: Henryk Szadziewski, How the West was Won: China’s expansion into Cenral Asia, Caucasian Review of International Affairs, numer 3, wiosna 2009.

$\mathrm{W}$ realizowanej polityce wobec prowincji stale obecny jest wektor środkowoazjatycki. W ciągu dwudziestu jeden lat od rozpadzie ZSRR, Chinom udało się osiągnąć status jednego z najważniejszych partnerów importowych i eksportowych dla pięciu środkowoazjatyckich republik ${ }^{42}$. W pierwszym roku po upadku ZSRR obroty handlowe pomiędzy Xinjiangiem a Azją Środkową wzrosły o 130 procent ${ }^{43}$, by w kolejnych latach kontynuować ten imponujący trend (Tabela 2).

daily.com.cn/china/2011-11/o6/content_14044742.htm, 28.02.2012 r.

${ }^{38}$ S. Ibraimov, China-Central Asia Trade Relations: Economic and Social Patterns, „The China and Eurasia Forum Quarterly” 2007, nr 1, s. 50.

${ }^{39}$ P. Trzaskowski, Chińska strategia powrotu do Azji Centralnej, [w:] Współczesny Daleki Wschód w stosunkach międzynarodowych - rywalizacja i mocarstwowość, red. D. K. Gemechu, 2008 s. 103.

${ }^{40} \mathrm{~S}$. Wei, Xinjiang builds foundation for rapid development, China Daily http:// www.chinadaily.com.cn/china/2011-03/03/content_12106955.htm, 27.02.2012 r.

${ }^{41}$ E. S. Bażenowa, Sincezjan i nowyje gorizonty welikowo szelikowowo puti, „Prostranstwjennaja Ekonomika” 2011, No. 2, s. 137.

${ }^{42}$ Asian Development Bank Key Indicators for Asia and the Pacific 2011.

${ }^{43}$ H. Yin, Z. Wang, Assessing China's influence in Central Asia: A dominant regional power?, The University of Nottingham, China Policy Institue, lipiec 2009, s. 2. 
Dla obywateli Tadżykistanu bądź Uzbekistanu chińskie towary konsumpcyjne są tańszą alternatywą niż ich amerykańskie, japońskie czy rosyjskie odpowiedniki, często nie ustępując im pod względem poziomu wykonania.

Gospodarcza penetracja rynków środkowoazjatyckich z perspektywy Pekinu traktowana jest jako jeden z głównych bodźców rozwojowych dla URA. Kierunek ten z pewnością będzie kontynuowany, zaś owocna współpraca na niwie gospodarczej wpłynie z kolei na umocnienie się więzi politycznych. 10 stycznia 2012 r. Chiny wraz z pięcioma państwami środkowoazjatyckimi obchodziły dwudziestą rocznicę nawiązania stosunków dyplomatycznych. Rocznica stała się okazją dla podkreślenie ewolucji jaka od 1992 r. zaszła we wzajemnych relacjach, oraz gotowości do dalszej kooperacji, szczególnie w budowie sfery wzajemnego bezpieczeństwa oraz realizacji wspólnych projektów gospodarczych ${ }^{44}$.

\section{Podsumowanie}

ZARÓWNO W PRASIE, JAK I PUBLIKACJACH NAUKOWYCH, dla określenia obecnej sytuacji w prowincji często używa się analogii z podbojem i kolonizacją Dzikiego Zachodu przez amerykańskich osadników, którzy budowali podwaliny gospodarczego i politycznego supermocarstwa 45 . O ile skala i tempo działań podjętych w URA - szczególnie w ostatnich latach - rzeczywiście mogą budzić wrażenie, to warto także zwrócić uwagę na wielowymiarowość polityki realizowanej przez Państwo Środka.

Intensywna działalność inwestycyjna w Xinjiangu doprowadzić ma do stopniowego wyrównywania się poziomu rozwoju pomiędzy bogatym chińskim wschodem a biedniejszym zachodem. Polityka migracyjna pozwala z kolei na odciążenie prowincji, w których presja ludnościowa doprowadza do granic możliwości eksploatacji zasobów naturalnych, stanowiąc poważną przeszkodzę dla ich przyszłego wzrostu gospodarczego.

W perspektywie międzynarodowej umacniana jest rola URA jako łącznika pomiędzy ChRL a Azją Środkową, która umożliwia realizację chińskiej strategii rozszerzenia wpływów w regionie poprzez inwestycje i handel.

${ }^{44}$ China, five Central Asian nations celebrate 2oth anniversary of diplomatic ties, Agencja Xinhua, http://news.xinhuanet.com/english/china/2012-01/10/c_131353190. htm, 27.02.2012 r.

${ }^{45}$ N. Swanström, China and Greater Central Asia: New Frontiers?, „Silk Road Paper" 2011, s. 41. 
Pekin liczy na to, iż polityka promująca rozwój gospodarczy i poprawę standardów życia wśród wszystkich grup etnicznych stanie się skutecznym narzędziem stabilizacji sytuacji w prowincji. Zadanie to może być jednak trudne do wykonania, jeśli rząd chiński nie zgodzi się na realizacje przynajmniej części postulatów mniejszości ujgurskiej, odnoszących się do respektowania konstytucyjnych praw związanych $\mathrm{z}$ autonomicznym statusem prowincji.

\section{SUMMARY}

THE MAIN PURPOSE OF THE ARTICLE IS TO PRESENT THE KEY ELEMENTS Of Chinese policy in Xinjiang. This western province represents $1 / 6$ of China's landmass and plays a significant role in Chinese security and economic policy. This study tries to show the complexity of challenges that Chinese have to face in their attitude to Xinjiang. For years, Xinjiang was known as a primary front in Chinese war on terrorism. That is why, a question whether the government uses the threat of terrorism as an excuse to violate minority rights is raised. Recently, China has been implementing a new policy, which is more concerned on economic development and improvement of living standards and could be a first step in a long way to stabilize the situation in the province.

\section{NotA O AUTORZE}

Szymon Mikołajczyk [szmikolajczyk@02.pl] - absolwent Instytutu Wschodniego na Wydziale Historycznym Uniwersytetu im. Adama Mickiewicza w Poznaniu, oraz student Międzynarodowych Stosunków Gospodarczych na Uniwersytecie Ekonomicznym. Stypendysta Tianjin University of Technology w ChRL. Jego zainteresowania naukowe skupiają się na polityce gospodarczej Chińskiej Republiki Ludowej oraz stosunkach międzynarodowych na obszarze Azji Centralnej i Wschodniej. 